\title{
Drivers of archaeal ammonia-oxidizing communities in soil
}

\author{
Kateryna Zhalnina ${ }^{1}$, Patrícia Dörr de Quadros ${ }^{2}$, Flavio A. O. Camargo ${ }^{2}$ and Eric W. Triplett ${ }^{\mathbf{1}}$ *
}

${ }^{1}$ Microbiology and Cell Science Department, Institute of Food and Agricultural Sciences, University of Florida, Gainesville, FL, USA

${ }^{2}$ Soil Science Department, Federal University of Rio Grande do Sul, Porto Alegre, Brazil

\section{Edited by:}

Rich Boden, University of Plymouth, USA

\section{Reviewed by:}

Jennifer F. Biddle, University of Delaware, USA

J. Michael Beman, University of California, Merced, USA

Nathan Basiliko, University of Toronto, Canada

\section{*Correspondence:}

Eric W. Triplett, Department of Microbiology and Cell Science, Institute of Food and Agricultural Sciences, University of Florida, 1052 Museum Road, Gainesville, FL 32611-0700, USA e-mail: ewt@ufl.edu
Soil ammonia-oxidizing archaea (AOA) are highly abundant and play an important role in the nitrogen cycle. In addition, AOA have a significant impact on soil quality. Nitrite produced by AOA and further oxidized to nitrate can cause nitrogen loss from soils, surface and groundwater contamination, and water eutrophication. The AOA discovered to date are classified in the phylum Thaumarchaeota. Only a few archaeal genomes are available in databases. As a result, AOA genes are not well annotated, and it is difficult to mine and identify archaeal genes within metagenomic libraries. Nevertheless, 16S rRNA and comparative analysis of ammonia monooxygenase sequences show that soils can vary greatly in the relative abundance of AOA. In some soils, AOA can comprise more than $10 \%$ of the total prokaryotic community. In other soils, AOA comprise less than $0.5 \%$ of the community. Many approaches have been used to measure the abundance and diversity of this group including DGGE, T-RFLP, q-PCR, and DNA sequencing. AOA have been studied across different soil types and various ecosystems from the Antarctic dry valleys to the tropical forests of South America to the soils near Mount Everest. Different studies have identified multiple soil factors that trigger the abundance of AOA. These factors include $\mathrm{pH}$, concentration of available ammonia, organic matter content, moisture content, nitrogen content, clay content, as well as other triggers. Land use management appears to have a major effect on the abundance of AOA in soil, which may be the result of nitrogen fertilizer used in agricultural soils. This review summarizes the published results on this topic and suggests future work that will increase our understanding of how soil management and edaphoclimatic factors influence AOA.

\section{Keywords: ammonia-oxidizing archaea, ammonia monooxygenase, soil}

\section{DISCOVERY OF THE AMMONIA-OXIDIZING ARCHAEA, THEIR TAXONOMY, PHYSIOLOGY, AND METABOLISM FIRST DISCOVERIES OF NOVEL GROUP}

Chemolithotrophic nitrification is a two-step process. First step includes oxidation of ammonia to nitrite conducted by ammoniaoxidizing bacteria $(\mathrm{AOB})$ and second step is conversion of nitrite to nitrate by nitrite-oxidizing bacteria (NOB; Hastings et al., 2000; Hermansson and Lindgren, 2001; Kowalchuk and Stephen, 2001). Before the discovery of large numbers of ammonia-oxidizing archaea (AOA) in the environment, aerobic ammonia-oxidizers were thought to be restricted to $\mathrm{AOB}$ from $\beta$ - and $\gamma$-subclasses of the Proteobacteria. The first published evidence that archaea might be involved in ammonia oxidation came from the discovery of archaeal homologs to bacterial ammonia monooxygenase gene ( $a m o A)$ in archaea-associated scaffolds from the whole genome shotgun sequencing project of the Sargasso Sea (Venter et al., 2004). An in silico comparison to environmental sequences from public databases revealed that the archaeal $a m o A$ and $a m o B$ genes from the large-insert environmental fosmid library of a calcareous grassland were highly similar to archaea-associated scaffolds from the Sargasso Sea (Treusch et al., 2005). This insert also contained a $16 \mathrm{~S}$ rRNA gene that proved that the organism from which this amoA homolog originated was a mesophilic Crenarchaeota. At the same time, Könneke et al. (2005) isolated a marine crenarchaeote (SCM1) that grows chemolithoautotrophically by aerobically oxidizing ammonia to nitrite. Wuchter et al. (2006) enriched a crenarchaeote from North Sea water and showed that its abundance, but not the abundance of AOB, correlates with ammonium oxidation to nitrite. The same study also found that archaeal amoA copy numbers were higher than bacterial amoA. Since the early work on Crenarchaeota, multiple studies have observed a predominance of $\mathrm{AOA}$ over $\mathrm{AOB}$ in multiple environments, particularly in soil (Leininger et al., 2006; Nicol et al., 2008; Schauss et al., 2009; Zhang et al., 2010).

\section{CLASSIFICATION: THAUMARCHAEOTA OR CRENARCHAEOTA?}

Initially, AOA were classified as mesophilic Crenarchaeota (Treusch et al., 2005). Brochier-Armanet et al. (2008) proposed that the archaeal ammonia oxidizers were sufficiently distinct to be separated from the Crenarchaeota into a new phylum, Thaumarchaeota. This distinction was based on phylogenetic analysis of ribosomal protein encoding genes and some protein-coding genes. Comparative phylogenetic analysis of marine and soil AOA revealed six conserved signature indels and more than 250 proteins unique only to the Thaumarchaeota (Spang et al., 2010). Also, Pelve etal. (2011) found that the Cdv system, related to the eukaryotic ESCRT-III machinery, is the primary cell division system in the thaumarchaeon Nitrosopumilus maritimus and that the FtsZ protein performs a function in archaea other than cell division. 


\section{ECOPHYSIOLOGY}

Ammonia-oxidizing archaea and $\mathrm{AOB}$ oxidize ammonia by using ammonia monooxygenase (AMO) enzyme. Although nitrite is the final product for both archaeal and bacterial ammonia oxidation, big differences exist between the AOA and AOB ammonia oxidation processes. First, the intermediate product of bacterial ammonia oxidation to nitrite is hydroxylamine (Kowalchuk and Stephen, 2001). The intermediate product of archaeal ammonia oxidation is not as clear, but nitroxyl has been proposed as the intermediate (Walker etal., 2010). Second, the structure of AMO differs between bacteria and archaea (Könneke et al., 2005; Walker et al., 2010). Third, archaeal AMO has a higher affinity for substrate than does bacterial AMO (Martens-Habbena et al., 2009; Martens-Habbena and Stahl, 2011). Fourth, while AOB are obligate autotrophs, AOA can also use organic carbon (Hallam et al., 2006; Walker et al., 2010; Blainey et al., 2011; Tourna etal., 2011). Differences listed above between AOA and AOB led to the idea of existence of different physiological approaches in utilizing of available nutrient resources between these two groups.

\section{DIFFICULTIES IN STUDYING AOA: CULTIVATION, LACK OF REFERENCE GENOMES}

To date, only eight AOA species have been described from marine, soil, sediment, and hot spring environments (Table 1). Two of them were isolated in pure cultures, and five species can grow in enriched cultures but were not isolated in pure cultures. Only six whole genomes of AOA are available in the databases. As the AOA have been found under a wide variety of conditions including varied temperature, $\mathrm{pH}$, ammonia concentrations, and oxygen supply, designing media for their cultivation has been difficult. The lack of a variety of cultured AOA and AOA genomes has limited the study of their physiology and metabolism.

\section{ECOLOGICAL ROLE OF AOA AND WHY STUDY THEM?}

First, AOA are likely involved in nitrate leaching from soils, which causes surface and groundwater contamination. Nitrogen loss can occur at many points during the nitrification process (Kowalchuk and Stephen, 2001). The nitrate produced during nitrification can lead to the elimination of fixed nitrogen from an environmental system. Nitrate leaching from soil is another important route of nitrogen loss from ecosystems. Cationic ammonium $\left(\mathrm{NH}_{4}{ }^{+}\right)$molecules are more stable in soil through binding to anionic soil particles, but nitrate $\left(\mathrm{NO}_{3}{ }^{-}\right)$has more mobility in soil and can easily leach from the soil surface to groundwater causing contamination (Kowalchuk and Stephen, 2001).

Second, AOA activity may be a significant source of greenhouse gas emissions from the soil. Recently, it was found that nitrous oxide $\left(\mathrm{N}_{2} \mathrm{O}\right)$ is the dominant ozone-depleting substance emitted in the 21st century (Ravishankara et al., 2011). Nitrous oxide is transported to the stratosphere where it destroys ozone through a nitrogen oxide-catalyzed process. Nitrous oxide has 298 times higher global warming potential than carbon dioxide $\left(\mathrm{CO}_{2}\right.$; van Groenigen et al., 2011). Autotrophic nitrification is a main pathway of nitrous oxide production in soil environments (Colliver and Stephenson, 2000; Kowalchuk and Stephen, 2001; Shaw et al., 2006). Santoro et al. (2011) suggested that AOA may be largely responsible for the nitrous oxide production in marine environments. As AOA outnumber AOB in soil, it is possible that archaea may be the major source of soil nitrous oxide emission. Jung et al. (2011) observed that production of nitrous oxide by the

Table 1 | Ammonia-oxidizing archaea isolated from different environments.

\begin{tabular}{|c|c|c|c|c|c|c|c|c|}
\hline \# & AOA & Environment & Source of isolation & $\begin{array}{l}\text { Classifi- } \\
\text { cation }\end{array}$ & Culture & $\begin{array}{l}\text { Genome } \\
\text { sequence }\end{array}$ & Reference & Country \\
\hline 1 & $\begin{array}{l}\text { Nitrosopumilus } \\
\text { maritimus }\end{array}$ & Marine & $\begin{array}{l}\text { Gravel from a marine } \\
\text { tropical fish tank }\end{array}$ & $1.1 \mathrm{a}$ & Pure & + & $\begin{array}{l}\text { Könneke etal. (2005), } \\
\text { Walker etal. (2010) }\end{array}$ & USA \\
\hline 2 & $\begin{array}{l}\text { Cenarchaeum } \\
\text { symbiosum }\end{array}$ & Marine symbiont & $\begin{array}{l}\text { Marine sponge } \\
\text { Axinellamexicana }\end{array}$ & $1.1 \mathrm{a}$ & - & + & $\begin{array}{l}\text { Preston etal. (1996), } \\
\text { Hallam etal. (2006) }\end{array}$ & USA \\
\hline 3 & $\begin{array}{l}\text { Ca. Nitrososphaera } \\
\text { gargensis }\end{array}$ & Soil, hot springs & $\begin{array}{l}\text { Enrichment cultures from } \\
\text { microbial mats of the } \\
\text { Siberian Garga hot spring }\end{array}$ & $1.1 b$ & Enriched & + & Hatzenpichler etal. (2008) & Austria \\
\hline 4 & $\begin{array}{l}\text { Nitrososphaera } \\
\text { viennensis }\end{array}$ & Soil & Garden soil in Vienna, Austria & $1.1 \mathrm{~b}$ & Pure & + & Tourna et al. (2011) & Austria \\
\hline 5 & $\begin{array}{l}\text { Ca. Nitrosoarchaeum } \\
\text { koreensis }\end{array}$ & Rhizosphere & $\begin{array}{l}\text { Soil sample from the rhizosphere } \\
\text { of Caraganasinica }\end{array}$ & $1.1 \mathrm{a}$ & Enriched & + & $\begin{array}{l}\text { Kim et al. (2011), } \\
\text { Jung et al. (2011) }\end{array}$ & $\begin{array}{l}\text { Republic } \\
\text { of Korea }\end{array}$ \\
\hline 6 & $\begin{array}{l}\text { Ca. Nitrosoarchaeum } \\
\text { limina }\end{array}$ & Sediments & $\begin{array}{l}\text { Sediments in the low-salinity } \\
\text { region of San Francisco Bay }\end{array}$ & $1.1 \mathrm{a}$ & Enriched & + & Blainey et al. (2011) & USA \\
\hline 7 & $\begin{array}{l}\text { Ca. Nitrosocaldus } \\
\text { yellowstonii }\end{array}$ & Hot springs & $\begin{array}{l}\text { Yellowstone National Park, } \\
\text { hot springs }\end{array}$ & ThAOA & Enriched & - & de la Torre etal. (2008) & USA \\
\hline 8 & $\begin{array}{l}\text { Ca. Nitrosotalea } \\
\text { devanaterra }\end{array}$ & Soil & Acidic agricultural soil & $\begin{array}{l}\text { 1.1a- } \\
\text { associated }\end{array}$ & Enriched & - & $\begin{array}{l}\text { Lehtovirta-Morley et al. } \\
\text { (2011) }\end{array}$ & UK \\
\hline
\end{tabular}


soil archaeon Ca. Nitrosoarchaeum koreensis and rates of nitrous oxide production are dependent on soil ammonia and dissolved oxygen (DO) concentration. To date, the mechanism of nitrous oxide production by archaea is unclear.

Possible consequences of autotrophic nitrification are contamination of surface and ground water, loss of soil fertility, emission of greenhouse gases, and chemical degradation of agricultural lands (Oldeman et al., 1991; Kowalchuk and Stephen, 2001; Ghosh and Dhyani, 2005; Santoro et al., 2011). AOA are frequently dominant ammonia oxidizers in soils (Leininger et al., 2006), and, therefore, their activity could lead to these consequences. Studying the abundance and composition of archaeal ammonia oxidizers and understanding how soil properties influence this group has long-lasting implications for sustainable agriculture and it attracts the attention of many research groups from around the world.

\section{EDAPHOCLIMATIC FACTORS THAT MAY INFLUENCE AOA ABUNDANCE AND DIVERSITY}

Main environmental factors that shape the ecological niches of AOA from the ocean, hot springs, soils, and sediments were discussed in the review paper by Erguder et al. (2009). Recent advances in ecology, genetics, physiology, and culturing happened in the field of AOA, such as sequencing of first genome of non-symbiotic marine AOA (Walker et al., 2010), obtaining pure cultures, and high enrichments of Nitrososphaera viennensis (Tourna et al., 2011), Ca. Nitrosoarchaeum koreensis, Ca. Nitrosoarchaeum limina, Ca. Nitrosotalea devanaterra and sequencing of their genome; discovery of AOA ecotypes in soils based on different pH levels (Gubry-Rangin et al., 2011) and another evidences of organic carbon utilization provided more information about physiology and metabolism of this group.

\section{AMMONIA OR AMMONIUM AS SUBSTRATE FOR AMMONIA MONOOXYGENASE}

Is ammonia $\left(\mathrm{NH}_{3}\right)$ or the cation ammonium $\left(\mathrm{NH}_{4}{ }^{+}\right)$the substrate for the archaeal AMO enzyme? Ammonia is known to be the substrate of this initial step in bacterial ammonia oxidation (Suzuki et al., 1974; Arp et al., 2002). However, despite several studies dedicated to studying the biochemistry of AMO in bacteria, it still remains unknown whether ammonia or ammonium is the substrate for archaeal AMO (Martens-Habbena and Stahl, 2011). Bacterial oxidation of ammonia to nitrite $\left(\mathrm{NO}_{2}{ }^{-}\right)$is a two-step process. AMO oxidizes ammonia to hydroxylamine $\left(\mathrm{NH}_{2} \mathrm{OH}\right)$, and hydroxylamine oxidoreductase (HAO) catalyzes oxidation of hydroxylamine to nitrite (Arp et al., 2002). Structural differences in the archaeal AMO and bacterial AMO and the absence of genes encoding $\mathrm{HAO}$ and cytochrome $c$ proteins for recycling electrons suggest important differences between bacterial and archaeal ammonia oxidation. For example, nitroxyl (HNO) rather than hydroxylamine may be the intermediate in the AMO enzymatic reaction, or a different cytochrome system may be responsible for electron channeling in AOA (Walker et al., 2010).

The majority of AOA discovered to date were found in oligotrophic conditions (Hatzenpichler et al., 2008; Walker et al., 2010). The affinity of marine archaeon Nitrosopumilus maritimus for ammonium/ammonia was 200-fold higher than substrate affinity of AOB (Martens-Habbena et al., 2009; Martens-Habbena and Stahl, 2011). These microorganisms can obtain energy even under very low concentrations of substrate. It has been suggested that the differences in substrate affinities allow $\mathrm{AOA}$ and $\mathrm{AOB}$ to inhabit distinct niches separated by substrate concentration and thereby reduce competition (Martens-Habbena et al., 2009; Schleper, 2010; Martens-Habbena and Stahl, 2011; Verhamme et al., 2011). There are studies that suggest substrate inhibition of archaeal nitrification if high concentrations of ammonia are present (Di et al., 2010; Tourna et al., 2010).

Because AMO in AOA has a much higher affinity for substrate than the analogous process in $\mathrm{AOB}$, it has been suggested that $\mathrm{AOA}$ dominate over $\mathrm{AOB}$ where ammonia concentrations are particularly low. This seems to be the case in oligotrophic environments such as sea water or hot springs (Hatzenpichler et al., 2008; Walker et al., 2010). For example, Ca. Nitrososphaera gargensis, which was first found in hot springs, fixes bicarbonate at lower levels when the ammonia concentration was higher than $3.1 \mathrm{mM}$. The optimal ammonia concentration for bicarbonate fixation was much lower, between 0.14 and $0.8 \mathrm{mM}$ (Hatzenpichler et al., 2008). Some studies suggest that substrate concentration does not influence thaumarchaeal ammonia oxidation (Stopnisek et al., 2010; Verhamme et al., 2011). These authors showed that AOA grew similarly at low, medium, and high ammonia concentrations, whereas $\mathrm{AOB}$ grew best only with high ammonia concentrations. Other factors were suggested to be important in the growth of AOA. Di et al. (2009) observed in nitrogen-rich grassland soils neither AOA abundance nor their activity increased with the application of a large dose of ammonia substrate. In this study, AOA abundance was not quantitatively related to nitrification rates. Similarly, Ke and Lu (2012) did not see any changes in AOA in paddy field soils after urea was applied as nitrogen fertilizer.

In some studies, high ammonia appears to promote AOA growth and activity. Treusch et al. (2005) found considerably higher amounts of archaeal $a m o A$ transcripts in those samples that had been amended with additional ammonia (10 $\mathrm{mM})$. It was demonstrated that the soil archaea Nitrososphaera viennensis strain EN76 grows well in media containing ammonium concentrations as high as $15 \mathrm{mM}$, but its growth is inhibited at $20 \mathrm{mM}$ (Tourna et al., 2011). This is considerably higher than the inhibitory concentration of $2-3 \mathrm{mM}$ reported for the aquatic AOA Nitrosopumilus maritimus (Walker et al., 2010) and Ca. Nitrososphaera gargensis (Hatzenpichler et al., 2008). Tolerance for ammonia toxicity of $\mathrm{Ca}$. Nitrosoarchaeum koreensis strain MY1, isolated from an acidic agricultural soil, was slightly lower, $5 \mathrm{mM}$, than that of Nitrososphaera viennensis (Jung et al., 2011). Park et al. (2006) found archaeal amoA in wastewater with $2 \mathrm{mM}$ ammonia.

The source of substrate and its location can influence ammonia concentration in soil (Offre et al., 2009; Stopnisek et al., 2010; Verhamme et al., 2011). Ammonium production via mineralization, additions of ammonical fertilizers, animal wastes, and the atmospheric deposition of ammonium increases substrate supply, while competing consumptive processes include microbial assimilation (immobilization), plant assimilation, and ammonia volatilization reduce ammonia concentration (Norton and Stark, 2011). 
In addition, $\mathrm{AOA}$ do not respond to the addition of mineral nitrogen to soil (Di et al., 2009; Jia and Conrad, 2009; Stopnisek et al., 2010; Verhamme et al., 2011; Ke and Lu, 2012). In contrast, AOB increase in abundance after addition of ammonium sulfate or urine (Di et al., 2009, 2010; Jia and Conrad, 2009; Hofferle et al., 2010). Archaeal amoA gene copies and nitrate concentration increased during incubation soil for 30 days (Offre et al., 2009). All ammonia in this soil was generated by nitrogen mineralization since no ammonia was added. Also, it was shown in upland field soils archaeal 16S rRNA gene was significantly affected by the class of fertilizer (chemical or organic fertilizer). In four different soil types $16 \mathrm{~S}$ rRNA abundance of AOA was about $0.1-0.9 \times 10^{8}$ gene copy number higher in the plots where organic fertilizers were added than in the plots with chemical fertilizer addition.

Nitrate concentrations likely differ greatly both spatially and temporally under these two scenarios (Stopnisek et al., 2010). While ammonia from organic matter mineralization is slowly and constantly liberated resulting in low, but steady, levels of ammonia, an application of mineral nitrogen fertilizer promotes a burst of ammonia. Archaeal ammonia oxidizers should be expected to be in a higher abundance in the soils with high organic matter, which would provide a constant source of substrate (Stopnisek et al., 2010).

Adaptation to different concentrations of ammonia and the ability to survive even at extremely low concentrations of ammonia, together with other ecological factors, contribute to the ecological fitness and niche adaptation of AOA and AOB. The presence of different ecophysiological adaptations such as different concentrations of substrate suggests that a wide range of ecotypes can be expected to occur among soil AOA.

\section{DIFFERENT LINEAGES OF AOA RESIDE AT DIFFERENT pH LEVELS}

Ammonia $\left(\mathrm{NH}_{3}\right)$, not ammonium $\left(\mathrm{NH}_{4}{ }^{+}\right)$, is the likely substrate for the AMO that catalyzes the initial step of the oxidation of ammonia (Arp et al., 2002). The ammonia form is $\mathrm{pH}$ dependent $\left(\mathrm{pKa}=9.25,25^{\circ} \mathrm{C}\right)$ and conversions between ionic and cationic forms may occur close to or at the cell membrane (Norton and Stark, 2011).

Ammonia-oxidizing archaea are more tolerant to low $\mathrm{pH}$ than $\mathrm{AOB}$, and $\mathrm{AOA}$ are mainly responsible for nitrification in acidic soils (Leininger et al., 2006; Gubry-Rangin et al., 2010; Yao et al., 2011; Zhang et al., 2011; Isobe et al., 2012). Archaeal amoA was found in conditions as low as $\mathrm{pH} 2.5$ in terrestrial hot springs (Reigstad etal., 2008), as high as pH 8.2 in North Sea water and sediments (Wuchter etal., 2006; Blainey et al., 2011), and at pH 9 at Eagleville spring in California (Zhang et al., 2008), where they were the only representatives of ammonia oxidizers. The lowest $\mathrm{pH}$ levels of soil in which AOA have been found are 3.6-4.0 (He et al., 2007; Yao et al., 2011). Nicol et al. (2008) reported that archaeal amo $A$ gene and transcript abundance decreased with higher $\mathrm{pH}$ during a soil microcosm experiment. Further study revealed an increase in archaeal amoA gene and transcript abundance during nitrification and inhibition of archaeal amoA, but not bacterial amoA, by acetylene addition in two agricultural acidic soils (Gubry-Rangin et al., 2010). Quantification of $1.1 \mathrm{c}$ crenarchaeal $16 \mathrm{~S}$ rRNA gene abundance through a $\mathrm{pH}$ gradient from 4.5 to 7.5 showed a greater proportion of this group in the most acidic soils (Lehtovirta et al., 2009). Yao et al. (2011) studied nitrification in tea orchard soils with low pH (3.66.3) and found that the high level of nitrification was driven by AOA but not AOB. In addition, AOA phylotypes found in highly acidic soils $(\mathrm{pH}<4)$ were negatively correlated with $\mathrm{pH}$, and AOA from soils with a higher $\mathrm{pH}(>4)$ showed a positive correlation with $\mathrm{pH}$ (Yao etal., 2011). Zhang et al. (2011) found archaea in five strongly acidic soils (between pH 4.2 and 4.47) where archaeal $a m o A$ gene abundance was strongly correlated with nitrate concentration. Recently Ca. Nitrosotalea devanaterra, the first obligate acidophilic ammonia oxidizer, was discovered and cultured from an agricultural acidic soil ( $\mathrm{pH} 4.5$; LehtovirtaMorley et al., 2011). This archaeon is able to grow at extremely low concentrations of ammonia $(0.18 \mathrm{nM})$ suggesting that this organism has evolved to tolerate the acidic conditions that make ammonia concentrations very low. As AOB have a lower affinity for ammonia, the low availability of ammonia under acidic conditions is believed to be the main reason for decreasing of ammonia oxidation by AOB in acidic soils (de Boer and Kowalchuk, 2001). In contrast, the high affinity for ammonia allows certain ecotypes of AOA to grow under low concentrations of ammonia (Nicol et al., 2008; Martens-Habbena et al., 2009; Gubry-Rangin et al., 2010).

Ammonia-oxidizing archaea also appear dominant under alkaline conditions as well as acidic conditions and are often more abundant than AOB at higher $\mathrm{pH}$ (Shen et al., 2008; Zhang et al., 2010; Bates et al., 2011). Shen et al. (2008) did not observe a significant correlation between $\mathrm{AOA}$ and $\mathrm{pH}$ in the alkaline soils ( $\mathrm{pH}$ 8.3-8.7), but the number of archaeal amoA genes did not decline with increasing $\mathrm{pH}$. In Cambisol soils ( $\mathrm{pH}$ 6-6.5), AOA were positively correlated with $\mathrm{pH}$ (Wessén et al., 2010).

Nitrification in alkaline soils ( $\mathrm{pH} 7.5)$ by AOA was demonstrated by Zhang et al. (2010). After incubation of soil with carbon dioxide, archaeal but not bacterial DNA was detected, and the number of archaeal amoA outnumbered bacterial amoA. Bates et al. (2011) studied changes in bacterial and archaeal communities in 146 soils across the globe and found a positive correlation between AOA with soil $\mathrm{pH}$, especially in forests and shrub lands. Bru et al. (2011) investigated the distribution of AOA communities over 107 sites in Burgundy, France, with $\mathrm{pH}$ ranging from 4.2 to 8.3 and found that in acidic soils AOA were below the detection level and AOA abundance positively correlated with soil $\mathrm{pH}$.

Different AOA ecotypes have evolved to growth at different $\mathrm{pH}$ levels. The existence of different environmental lineages was suggested by Nicol et al. (2008) and supported by Gubry-Rangin et al. (2011). Gubry-Rangin et al. (2011) clustered archaeal amoA sequences from globally distributed soils that varied widely in $\mathrm{pH}$. They found that all studied phylogenetic lineages were classified as acidophilic (lineage $\mathrm{C}$ - including Group 1.1a-associated), acido-neutrophilic (linage A - including Group 1.1a), and alkalinophilic (linage B - including Group 1.1b). These lineages vary in their response to $\mathrm{pH}$ but overall, archaeal amoA abundance increased with increasing $\mathrm{pH}$. $\mathrm{pH}$ appears to be a strong factor in many studies, but AOA are successful across a range of $\mathrm{pH}$ values. 


\section{CARBON}

Are AOA autotrophic, heterotrophic, or mixotrophic with regard to carbon utilization? Components of the modified 3-hydroxypropionate/4-hydroxybutyrate cycle of autotrophic carbon assimilation were identified in genomes of Cenarchaeum symbiosum (Hallam et al., 2006), Nitrosopumilus maritimus (Walker et al., 2010), Ca. Nitrosotalea devanaterra (Lehtovirta-Morley et al., 2011), and Ca. Nitrosoarchaeum limnia (Blainey et al., 2011). Ca. Nitrososphaera gargensis (Hatzenpichler et al., 2008) and Nitrososphaera viennensis can use carbon dioxide as sole carbon source (Tourna etal., 2011). Zhang et al. (2010) provided direct evidences for autotrophic activity and autotrophic growth of Thaumarchaeota in soil. Nitrification rates in this study correlated with increased archaeal, but not bacterial, amoA and hcd (key gene in 3-hydroxypropionate/4-hydroxybutyrate cycle) genes' abundances. Also, stable isotope probing showed incorporation of ${ }^{13} \mathrm{C}$-labeled carbon dioxide into archaeal amoA during nitrification but not into bacterial amoA. In addition, mRNA-SIP supported autotrophic carbon dioxide fixation by AOA using the 3-hydroxypropionate/4-hydroxybutyrate cycle in an agricultural soil (Pratscher et al., 2011).

Later evidence builds the case that some AOA take up organic carbon compounds, but others may be inhibited by organics. The first finding of the uptake of amino acids by planktonic archaea was shown by Ouverney and Fuhrman (2000). Herndl et al. (2005) and Teira etal. (2004) indicated the uptake of amino acids by isotopic studies of microbial communities in the Atlantic Ocean and speculated that this could be an indication of the utilization of the dissolved organic matter as an energy source.

Recent sequencing of AOA genomes and the culturing of AOA have supported mixotrophy by these organisms. Oxidative and reductive tricarboxylic acid cycle (TCA) genes were found in the genome Cenarchaeum symbiosum (Hallam et al., 2006). In addition to the genes that code for the 3-hydroxypropionate/ 4-hydroxybutyrate pathway, the Nitrosopumilus maritimus genome contains genes encoding for the complete oxidative TCA cycle (Walker etal., 2010) as well as transporters for amino acids, dipeptides/oligopeptides, sulfonates/taurine, and glycerol. Putative organic carbon consumption was suggested based on genome sequence of Ca. Nitrosoarchaeum limnia (Blainey et al., 2011). Increased growth of Nitrososphaera viennensis cultures by small additions of pyruvate (Tourna et al., 2011) also supports mixotrophic growth by AOA.

Chen et al. (2008) reported a higher abundance of AOA in the paddy rhizosphere compared to non-rhizosphere soil, presumably due to organic carbon of root exudates. Increased abundance of 1.1b AOA clade occurred upon the addition of root extract as an organic amendment to the AOA enrichment culture (Xu et al., 2012). Nevertheless, organic substrates have been shown to inhibit AOA or be negatively correlated with AOA abundance (Könneke et al., 2005; Wessén et al., 2010; Bates et al., 2011). Pester et al. (2012) also revealed negative correlation of AOA species richness to the organic carbon content in four geographically and chemically distinct soils. Although, genetic capacity to potentially use organic carbon and some cases of small organic molecules uptake by AOA were found by recent studies, there is still lack of understanding how exactly AOA use organic carbon.

\section{TEMPERATURE}

Temperature is one of the most significant factors that affect soil organic matter decomposition, nitrification, and greenhouse gas production in terrestrial environments (Kirschbaum, 1995; Stark and Firestone, 1996). Although optimal temperatures for potential nitrification are usually between 20 and $37^{\circ} \mathrm{C}$, the AOA produce nitrite at temperatures that vary from $-1{ }^{\circ} \mathrm{C}$ in Arctic coastal waters to $97^{\circ} \mathrm{C}$ in hot springs of Iceland (Reigstad et al., 2008; Kalanetra et al., 2009).

Archaeal amoA was detected in near-freezing Arctic and Antarctic waters with $4.92 \times 10^{6}$ and $0.18 \times 10^{6}$ copies, respectively (Kalanetra et al., 2009). Christman et al. (2011) analyzed distribution of AOA during summer $\left(\mathrm{T}=5.1^{\circ} \mathrm{C}\right)$ and winter $\left(\mathrm{T}=-1.7^{\circ} \mathrm{C}\right)$ in the Coastal Arctic Ocean and found that AOA amoA levels and nitrification rates were higher in winter.

The majority of AOA identified in soil and marine environments are non-thermophilic and are typically found at temperatures from 22 to $37^{\circ} \mathrm{C}$ (Könneke et al., 2005; Hallam et al., 2006; Muller et al., 2010; Blainey et al., 2011; Jung et al., 2011; Kim etal., 2011; Lehtovirta-Morley etal., 2011; Tourna et al., 2011). The thermophilic AOA detected in deep-sea hydrothermal vents and hot springs perform nitrification at temperatures of $45-97^{\circ} \mathrm{C}$ (de la Torre et al., 2008; Hatzenpichler et al., 2008; Reigstad etal., 2008; Wang etal., 2009; Zhang etal., 2011). A moderately thermophilic $\left(46^{\circ} \mathrm{C}\right)$ archaeon, $\mathrm{Ca}$. Nitrososphaera gargensis, discovered in microbial mats of the Siberian Garga hot spring was the dominant ammonia oxidizer in terrestrial nonthermophilic environments. Archaeal adaptations to function under elevated temperatures was demonstrated when different temperatures for fermenting cattle manure compost revealed growth of $\mathrm{AOB}$ at $37^{\circ} \mathrm{C}$, whereas $\mathrm{AOA}$ continue to grow upto $60^{\circ} \mathrm{C}$ (Oishi et al., 2011).

The impact of different temperatures on AOA populations was examined in field and microcosm experiments. Tourna et al. (2008) studied the responses of AOA and AOB during incubation of soil microcosms at temperatures in the range $10-30^{\circ} \mathrm{C}$. They determined that the most profound changes in patterns of archaeal $a m o A$ gene transcript abundance occurred at $30^{\circ} \mathrm{C}$. Stres et al. (2008) found that soil archaeal, but not bacterial, community structure changed during incubation at higher temperatures. A global survey of different soils showed a positive correlation between relative archaeal abundance and annual temperatures, and temperature became even more significant factor for the relative abundance of archaea from forests and shrub lands (Bates et al., 2011).

\section{MOISTURE}

Soil moisture and temperature impacts on main processes of nitrogen cycle, such as organic matter mineralization, nitric and nitrous oxide production, nitrogen fixing, and particularly, nitrification (Kirschbaum, 1995; Zheng et al., 2000; Belnap, 2001; Norton and Stark, 2011). Soil moisture promoted changes in the archaeal community in grassland soil microcosm (Stres et al., 2008). Bates et al. (2011) observed a negative correlation of soil moisture in tall grass prairies with AOA abundance. Diversity of soil microbial communities along a steep precipitation gradient ranging from an arid area with less than $100 \mathrm{~mm}$ annual rain to a meso-Mediterranean 
forest receiving over $900 \mathrm{~mm}$ precipitation was studied. Of measured physicochemical factors, water content was found to have the strongest correlation with the bacterial and archaeal community structures in studied soils (Angel et al., 2010).

Study of nitrogen and water amendment in two temperate forest soils revealed that the AOA community composition was sensitive to moisture content in one of the soils and archaeal amo $A$ genes were more abundant at $40 \%$ than $70 \%$ water-filled pore space suggesting reduced oxygen levels lowered AOA growth (Szukics et al., 2012).

\section{OXYGEN AND OTHER FACTORS}

Oxygen plays an important role in nitrification as a substrate for the AMO enzyme and as terminal electron acceptor (Arp et al., 2002). In soil, oxygen levels are balanced by oxygen consumption and diffusion from the surface through the air-filled pores (Sexstone et al., 1985). Nitrification usually declines in soil if water levels have exceeded field capacity for several days (Schjonning et al., 2003) thereby decreasing oxygen content. Tolerance to low concentrations of DO was demonstrated in activated sludge bioreactors with low DO ( $<6.3 \mu \mathrm{M}$; Park et al., 2006). In subterranean estuaries at low-oxygen fresh and brackish stations, AOA were 10 times more abundant than AOB (Santoro et al., 2011). Bouskill et al. (2012) examined the distribution AOA across large-scale gradients in DO as one of the important factors of AOA distribution in marine environments. The highest abundance of the AOA amoA gene was recorded in the oxygen minimum zones (OMZs) of the Eastern Tropical South Pacific (ETSP) and the Arabian Sea (AS). AOA in the AS exhibited a very narrow range of preferred oxygen conditions (5-2.5 $\mu \mathrm{M}$; Pitcher et al., 2011). Stoichiometry and kinetic of ammonium oxidation by Nitrosopumilus maritimus showed the endogenous oxygen uptake of the cells was consistently below $0.5 \mu \mathrm{M}$ per hour, but after addition of ammonium to the cells, oxygen uptake increased within a few minutes up to $30 \mu \mathrm{M} \mathrm{h}^{-1}$ and remained high until the ammonium level declined below $1 \mu \mathrm{M}$ (Martens-Habbena and Stahl, 2011). AOA and AOB are adapted to life in low-oxygen or periodically anoxic habitats in paddy soils. Although flooding paddy soil is predominantly anaerobic, large numbers of AOA were detected $\left(8.31 \times 10^{7}-2.12 \times 10^{8}\right.$

\section{REFERENCES}

Angel, R., Soares, M. I., Ungar, E. D., and Gillor, O. (2010). Biogeography of soil archaea and bacteria along a steep precipitation gradient. ISME J. 4, 553-563.

Arp, D. J., Sayavedra-Soto, L. A., and Hommes, N. G. (2002). Molecular biology and biochemistry of ammonia oxidation by Nitrosomonas europaea. Arch. Microbiol. 178, 250-255.

Bates, S. T., Berg-Lyons, D., Caporaso, J. G., Walters, W. A., Knight, R., and Fierer, N. (2011). Examining the global distribution of dominant archaeal populations in soil. ISME J. 5, 908-917.

Belnap, J. (2001). "Factors influencing nitrogen fixation and nitrogen release

copies per gram dry soil). Moreover, AOA reacted faster to the presence of oxygen in fluctuating oxic and anoxic rhizosphere of rice plants compared to AOB (Chen et al., 2008). Enrichment culture of Ca. Nitrososphaera gargensis was grown aerobically at DO concentrations $0.15-1.18 \mathrm{mM}$. Kinetic respirometry assays showed that Ca. Nitrosoarchaeum koreensis strain MY1's affinities for oxygen $(1.08 \mu \mathrm{M})$ were much higher than those of $\mathrm{AOB}$ (Jung et al., 2011).

Among the factors listed above there are many other factors that were shown to have some impact on AOA community. These include altitude (Zhang et al., 2009), soil types (Hoshino et al., 2011; Morimoto et al., 2011), sulfide (Caffrey et al., 2007; Coolen et al., 2007), phosphate (Herfort et al., 2007), and salinity (Bernhard et al., 2010). However, these factors either do not have a significant impact on archaeal ammonia oxidation or have not been found to influence soil AOA.

\section{CONCLUDING REMARKS}

The AOA are a versatile, ubiquitous, and abundant group of microorganisms that have adapted to survive in a wide variety of harsh environments. Moreover, their important function in the nitrogen cycle, and their roles in nitrate leaching, greenhouse gas production, and soil subsidence make the AOA a group that deserves further studies. Knowing the main drivers of AOA abundance and distribution in soil is of growing interest around the world. There are many studies that assess marine environmental AOA communities, but much less is known about soil AOA. Soil features that have major influence on shaping AOA communities include ammonia concentration, $\mathrm{pH}$, organic matter, moisture, temperature, and oxygen. AOA possess high affinities for ammonia and oxygen and can tolerate extremes of temperature and $\mathrm{pH}$. These features explain why the AOA greatly outnumber the $\mathrm{AOB}$ in many soils and other environments, as they can inhabit potential niches that are not available to the AOB.

\section{ACKNOWLEDGMENT}

Publication of this article was funded in part by the University of Florida Open-Access Publishing Fund.

1-12. doi: 10.1371/journal.pone. 0016626

Bouskill, N. J., Eveillard, D., Chien, D., Jayakumar, A., and Ward, B. B. (2012). Environmental factors determining ammonia-oxidizing organism distribution and diversity in marine environments. Environ. Microbiol. 14, 714-729.

Brochier-Armanet, C., Boussau, B. Gribaldo, S., and Forterre, P. (2008). Mesophilic crenarchaeota: proposal for a third archaeal phylum, the Thaumarchaeota. Nat. Rev. Microbiol. 6, 245-252.

Bru, D., Ramette, A., Saby, N. P. A., Dequiedt, S., Ranjard, L, Jolivet, C., Arrouays D., and Philippot, L. (2011). Determinants of the distribution of nitrogen-cycling microbial communities at the landscape scale. ISME J. 5, 532-542.

Caffrey, J. M., Bano, N., Kalanetra, K., and Hollibaugh, J. T. (2007). Ammonia oxidation and ammonia-oxidizing bacteria and archaea from estuaries with differing histories of hypoxia. ISME J. 1, 660-662.

Chen, X., Zhu, Y., Xia, Y., Shen, J., and He, J. (2008). Ammonia-oxidizing archaea: important players in paddy rhizosphere soil? Environ. Microbiol. 10, 1978-1987.

Christman, G. D., Cottrell, M. T., Popp, B. N., Gier, E., and Kirchman, D. L. (2011). Abundance, diversity, and activity of ammoniaoxidizing prokaryotes in the coastal arctic ocean in summer and winter. 
Appl. Environ. Microbiol. 77, 20262034.

Colliver, B. B., and Stephenson, T. (2000). Production of nitrogen oxide and dinitrogen oxide by autotrophic nitrifiers. Biotechnol. Adv. 18, 219-232.

Coolen, M. J. L., Abbas, B., van Bleijswijk, J., Hopmans, E. C., Kuypers, M. M. M., Wakeham, S. G., and Sinninghe Damste, J. S. (2007). Putative ammonia-oxidizing crenarchaeota in suboxic waters of the Black Sea: a basin-wide ecological study using $16 \mathrm{~S}$ ribosomal and functional genes and membrane lipids. Environ. Microbiol. 9, 1001-1016.

de Boer, W., and Kowalchuk, G. A. (2001). Nitrification in acid soils: microorganisms and mechanisms. Soil Biol. Biochem. 33, 853-866.

de la Torre, J. R., Walker, C. B., Ingalls, A. E., Könneke, M., and Stahl, D. A. (2008). Cultivation of a thermophilic ammonia oxidizing archaeon synthesizing crenarchaeol. Environ. Microbiol. 10, 810-818.

Di, H. J., Cameron, K. C., Shen, J. P., Winefield, C. S., O'Callaghan, M., Bowatte, S., and $\mathrm{He}$, J. Z. (2009). Nitrification driven by bacteria and not archaea in nitrogenrich grassland soils. Nat. Geosci. 2, 621-624.

Di, H. J., Cameron, K. C., Shen, J. P., Winefield, C. S., O'Callaghan, M., Bowatte, S., and He, J. Z. (2010). Ammonia-oxidizing bacteria and archaea grow under contrasting soil nitrogen conditions. FEMS Microbiol. Ecol. 72, 386-394.

Erguder, T. H., Boon, N., Wittebolle, L., Marzorati, M., and Verstraete, W. (2009). Environmental factors shaping the ecological niches of ammonia-oxidizing archaea. FEMS Microbiol. Ecol. Rev. 33, 855-869.

Ghosh, P., and Dhyani, P. P. (2005). Nitrogen mineralization, nitrification and nitrifier population in a protected grassland and rainfed agricultural soil. Trop. Ecol. 46, 173-181.

Gubry-Rangin, C., Hai, B., Quince, C., Engel, M., Thomson, B. C., James, P., Schloter, M., Griffiths, R. I., Prosser, J. I., and Nicol, G. W. (2011). Niche specialization of terrestrial archaeal ammonia oxidizers. Proc. Natl. Acad. Sci. U.S.A. 108, 2120621211.

Gubry-Rangin, C., Nicol, G. W., and Prosser, J. I. (2010). Archaea rather than bacteria control nitrification in two agricultural acidic soils. FEMS Microbiol. Ecol. 74, 566-574.

Hallam, S. J., Mincer, T. J., Schleper, C., Preston, C. M., Roberts, K.,
Richardson, P. M., and DeLong, E. F. (2006). Pathways of carbon assimilation and ammonia oxidation suggested by environmental genomic analyses of marine Crenarchaeota. PLoS Biol. 4, 0520-0536. doi: 10.1371/journal.pbio.0040095

Hastings, R. S., Butler, C., Singleton, I., Saunders, J. R., and McCarthy, A. J. (2000). Analysis of ammoniaoxidizing bacteria populations in acid forest soil during conditions of moisture limitation. Lett. Appl. Microbiol. 30, 14-18.

Hatzenpichler, R., Lebedeva, E. V., Spieck, E., Stoecker, K., Richter, A., Daims, H., and Wagner, M. (2008). A moderately thermophilic ammoniaoxidizing crenarchaeote from a hot spring. Proc. Natl. Acad. Sci. U.S.A. 6, 2134-2139.

He, J., Shen, J., Zhang, L., Zhu, Y., Zheng, Y., Xu, M., and Di, H. (2007). Quantitative analyses of the abundance and composition of ammonia-oxidizing bacteria and ammonia-oxidizing archaea of a Chinese upland red soil under longterm fertilization practices. Environ. Microbiol. 9, 2364-2374.

Herfort, L., Schouten, S., and Abbas, B. (2007). Variations in spatial and temporal distribution of Archaea in the North Sea in relation to environmental variables. FEMS Microbiol. Ecol. 62, 242-257.

Hermansson, A., and Lindgren, P. E. (2001). Quantification of ammoniaoxidizing bacteria in arable soil by real-time PCR. Appl. Environ. Microbiol. 67, 972-976.

Herndl, G. J., Reinthaler, T., Teira, E., Aken, H., Veth, C., Pernthaler, A. and Pernthaler, J. (2005). Contribution of Archaea to total prokaryotic production in the deep Atlantic ocean. Appl. Environ. Microbiol. 71, 2303-2309.

Hofferle, S., Nicol, G. W., Pal, L., Hacin, J., Prosser, J. I., and MandicMulec, I. (2010). Ammonium supply rate influences archaeal and bacterial ammonia oxidizers in a wetland soil vertical profile. FEMS Microbiol. Ecol. 74, 302-315.

Hoshino, Y. T., Morimoto, S., Hayatsu, M., Nagaoka, K., Suzuki, C., Karasawa, T., Takenaka, M., and Akiyama, H. (2011). Effect of soil type and fertilizer management on archaeal community in upland field soils. Microbes Environ. 26, 307-316.

Isobe, K., Koba, K., Suwa, Y., Ikutani, J., Fang, Y., Yoh, M., Mo, J., Otsuka, S., and Senoo, K. (2012). High abundance of ammonia-oxidizing archaea in acidified subtropical forest soils in southern China after long-term $\mathrm{N}$ deposition. FEMS Microbiol. Ecol. 80, 193-203.

Jia, Z. J., and Conrad, R. (2009). Bacteria rather than Archaea dominate microbial ammonia oxidation in an agricultural soil. Environ. Microbiol. $11,1658-1671$.

Jung, M. Y., Park, S. J., Min, D., Kim, J. S., Rijpstra, W. I., Damsté, J. S., Kim, G. J., Madsen, E. L., and Rhee, S. K. (2011). Enrichment and characterization of an autotrophic ammoniaoxidizing archaeon of mesophilic crenarchaeal Group I. 1a from an agricultural soil. Appl. Environ. Microbiol. 77, 8635-8647.

Kalanetra, K. M., Bano, N., and Hollibaugh, J. T. (2009). Ammoniaoxidizing Archaea in the Arctic Ocean and Antarctic coastal waters. Environ. Microbiol. 11, 2434-2445.

Ke, X., and Lu, Y. (2012). Adaptation of ammonia-oxidizing microbes to environment shift of paddy field soil. FEMS Microbiol. Ecol. 80, 87-97.

Kim, B. K., Jung, M. Y., Yu, D. S., Park, S. J., Oh, T. K., Rhee, S. K., and Kim, J. F. (2011). Genome sequence of an ammonia-oxidizing soil archaeon, "Candidatus Nitrosoarchaeum koreensis” MY1. J. Bacteriol. 193, 5539-5540.

Kirschbaum, M. U. (1995). The temperature dependence of soil organic matter decomposition, and the effect of global warming on soil organic C storage. Soil Biol. Biochem. 27, 753-760.

Könneke, M., Bernhard, A. E., de la Torre, J. R., Walker, C. B., Waterbury, J. B., and Stahl, D. A. (2005). Isolation of an autotrophic ammoniaoxidizing marine archaeon. Nature 437, 543-546.

Kowalchuk, G. A., and Stephen, J. A. (2001). Ammonia-oxidizing bacteria: a model for molecular microbial ecology. Annu. Rev. Microbiol. 55 485-529.

Lehtovirta, L. E., Prosser, J. E., and Nicol, G. W. (2009). Soil pH regulate the abundance and diversity of Group 1.1c Crenarchaeota. FEMS Microbiol. Ecol. 70, 367-376.

Lehtovirta-Morley, L. E., Stoecker, K., Vilcinskas, A., Prosser, J. I., and Nicol, G. W. (2011). Cultivation of an obligate acidophilic ammonia oxidizer from a nitrifying acid soil. Proc. Natl. Acad. Sci. U.S.A. 108, 15892-15897.

Leininger, S., Urich, T., Schloter, M., Schwark, L., Qi, J., Nicol, G. W., Prosser, J. I., Schuster, S. C., and Schleper, C. (2006). Archaea predominate among ammonia-oxidizing prokaryotes in soils. Nature 442, 806-809.
Martens-Habbena, W., Berube, P. M, Urakawa, H., de la Torre, J. R, and Stahl, D. A. (2009). Ammonia oxidation kinetics determines niche separation of nitrifying Archaea and Bacteria. Nature 461, 976-979.

Martens-Habbena, W., and Stahl, D. A. (2011). Nitrogen metabolism and kinetics of ammonia-oxidizing archaea. Methods Enzymol. 496, 465-487.

Morimoto, S., Hayatsu, M., Hoshino, Y. T., Nagaoka, K., Yamazaki, M. Karasawa, T., Takenaka, M., and Akiyama, H. (2011). Quantitative analyses of ammonia-oxidizing archaea (AOA) and ammonia-oxidizing bacteria $(\mathrm{AOB})$ in fields with different soil types. Microbes Environ. 26, 248-253.

Muller, F., Brissac, T., Le Bris, N., Felbeck H., and Gros, O. (2010). First description of giant Archaea (Thaumarchaeota) associated with putative bacterial ectosymbionts in a sulfidic marine habitat. Environ. Microbiol. 12, 2371-2383.

Nicol, G. W., Leininger, S., Schleper, C., and Prosser, J. I. (2008). The influence of soil $\mathrm{pH}$ on the diversity, abundance and transcriptional activity of ammonia oxidizing archaea and bacteria. Environ. Microbiol. 10, 2966-2978.

Norton, J. M., and Stark, J. M. (2011). Regulation and measurement of nitrification in terrestrial systems. Methods Enzymol. 486, 343-368.

Offre, P., Prosser, J. I., and Nicol, G. W. (2009). Growth of ammoniaoxidizing archaea in soil microcosms is inhibited by acetylene. FEMS Microbiol. Ecol. 70, 99-108.

Oishi, R., Tada, C., Asano, R., Yamamoto, N., Suyama, Y., and Nakai, Y. (2011). Growth of ammoniaoxidizing archaea and bacteria in cattle manure compost under various temperatures and ammonia concentrations. Microbes Ecol. doi: 10.1007/ s00248-011-9971-z [Epub ahead of print].

Oldeman, L. R., Hakkeling, R. T. A., and Sombroek, W. G. (1991). World Map of the Status of Human-induced Soil Degradation (GLASOD): An Explanatory Note. Wageningen: International Soil Reference and Information Centre.

Ouverney, C. C., and Fuhrman, J. A. (2000). Marine planktonic archaea take up amino acids. Appl. Environ. Microbiol. 66, 4829-4833.

Park, H., Wells, G. F., Bae, H., Criddle, C. S., and Francis, C. A. (2006). Occurrence of ammonia-oxidizing archaea 
in wastewater treatment plant bioreactors. Appl. Environ. Microbiol. 72, 5643-5647.

Pelve, E., Lindås, A. C., MartensHabbena, W., de la Torre, J. R., Stahl, D. A., and Bernander, R. (2011). Cdv-based cell division and cell cycle organization in the thaumarchaeon Nitrosopumilus maritimus. Mol. Microbiol. 82, 555-566.

Pester, M., Rattei, T., Flench, S., Gröngröft, A., Richter, A., Overmann, J., Reinhold-Hurek, B., Loy, A., and Wagner, M. (2012). amoA-based consensus phylogeny of ammonia-oxidizing archaea and deep sequencing of amoA genes from soils of four different geographic regions. Environ. Microbiol. 14, 525-539.

Pitcher, A., Villanueva, L., Hopmans, E. C., Schouten, S., Reichart, G., and Sinninghe Damste, J. S. (2011). Niche segregation of ammonia-oxidizing archaea and anammox bacteria in the Arabian Sea oxygen minimum zone. ISME J. 5, 1896-1904.

Pratscher, J., Dumont, M. J., and Conrad, R. (2011). Ammonia oxidation coupled to $\mathrm{CO}_{2}$ fixation by archaea and bacteria in an agricultural soil. Proc. Natl. Acad. Sci. U.S.A. 108, 4170-4175.

Preston, C. M., Wu, K. M., Molinski, T. F., and Delong, E. F. (1996). A psychrophilic crenarchaeon inhabits a marine sponge: Cenarchaeum symbiosum gen. nov., sp. nov. Proc. Natl. Acad. Sci. U.S.A. 93, 6241-6246.

Ravishankara, A. R., Daniel, J. S., and Portmann, R. W. (2011). Nitrous oxide $\left(\mathrm{N}_{2} \mathrm{O}\right)$ : the dominant ozone-depleting substance emitted in the 21st century. Science 326, 123-125.

Reigstad, L. J., Richter, A., Daims, H., Urich, T., Schwark, L., and Schleper, C. (2008). Nitrification in terrestrial hot springs of Iceland and Kamchatka. FEMS Microbiol. Ecol. 64, 167-174.

Santoro, A. E., Buchwald, C., McIlvin, M. R., and Casciotti, K. L. (2011). Isotopic signature of $\mathrm{N}_{2} \mathrm{O}$ produced by marine ammonia-oxidizing archaea. Science 333, 1282-1285.

Schauss, K., Focks, A., Leininger, S., Kotzerke, A., Heuer, H., ThieleBruhn, S., Sharma, S., Wilke, B. M., Matthies, M., Smalla, K., Munch, J. C., Amelung, W., Kaupenjohann, M., Schloter, M., and Schleper, C. (2009). Dynamics and functional relevance of ammoniaoxidizing Archaea in two agricultural soils. Environ. Microbiol. 11, 446-456.
Schjonning, P., Thomsen, I. K., Moldrup, P., and Christensen, B. T. (2003). Linking soil microbial activity to water- and air-phase contents and diffusivities. Soil Sci. Soc. Am. J. 67, 156-165.

Schleper, C. (2010). Ammonia oxidation: different niches for bacteria and archaea? ISME J. 4, 1092-1094.

Sexstone, A. J., Revsbech, N. P., Parkin, T. B., and Tiedje, J. M. (1985). Direct measurement of oxygen profiles and denitrification rates in soil aggregates. Soil Sci. Soc. Am. J. 49, 645-651.

Shaw, L. J., Nicol, G. W., Smith, Z., Fear, J., Prosser, J. I., and Baggs, E. M. (2006). Nitrosospira spp. can produce nitrous oxide via a nitrifier denitrification pathway. Environ. Microbiol. 8, 214-222.

Shen, J., Zhang, L., Zhu, Y., Zhang, J., and He, J. (2008). Abundance and composition of ammonia-oxidizing bacteria and ammonia-oxidizing archaea communities of an alkaline sandy loam. Environ. Microbiol. 10, 1601-1611.

Spang, A., Hatzenpichler, R., BrochierArmanet, C., Rattei, T., Tischler, P., Spieck, E., Streit, W., Stahl, D. A., Wagner, M., and Schleper, C. (2010). Distinct gene set in two different lineages of ammonia-oxidizing archaea supports the phylum Thaumarchaeota. Trends Microbiol. 18, 331-340.

Stark, J. M., and Firestone, M. K. (1996). Kinetic characteristics of ammonium-oxidizer communities in California oak woodland-annual grassland. Soil Biol. Biochem. 28, 1307-1317.

Stopnisek, N., Gubry-Rangin, C., Höfferle, S., Nicol, G. W., MandicMulec, I., and Prosser, J. I. (2010). Thaumarchaeal ammonia oxidation in an acidic forest peat soil is not influenced by ammonium amendment. Appl. Environ. Microbiol. 76, 7626-7634.

Stres, B., Danevcic, T., Pal, L., Fuka, M. M., Resman, L., Leskovec, S., Hacin, J., Stopar, D., Mahne, I., and Mandic-Mulec, I. (2008). Influence of temperature and soil water content on bacterial, archaeal and denitrifying microbial communities in drained fen grassland soil microcosms. FEMS Microbiol. Ecol. 66, 110-122.

Suzuki, I., Dular, U., and Kwok, S. C. (1974). Ammonia or ammonium ion as substrate for oxidation by Nitrosomonas europaea cells and extracts. J. Bacteriol. 120, 1181-1191.

Szukics, U., Hackla, E., ZechmeisterBoltenstern, S., and Sessitsch,
A. (2012). Rapid and dissimilar response of ammonia oxidizing archaea and bacteria to nitrogen and water amendment in two temperate forest soils. Microbiol. Res. 67, 103-109.

Teira, E., Reinthaler, T., Pernthaler, A., Pernthaler, J., and Herndl, G. J. (2004). Combining catalyzed reporter deposition-fluorescence in situ hybridization and microautoradiography to detect substrate utilization by bacteria and archaea in the deep ocean. Appl. Environ. Microbiol. 70, 4411-4414

Tourna, M., Freitag, T. E., Nicol, G. W., and Prosser, J. I. (2008). Growth, activity and temperature responses of ammonia-oxidizing archaea and bacteria in soil microcosms. Environ. Microbiol. 10, 1357-1364.

Tourna, M., Freitag, T. E., and Prosser, J. I. (2010). Stable isotope probing analysis of interactions between ammonia oxidizers. Appl. Environ. Microbiol. 76, 2468-2477.

Tourna, M., Stieglmeier, M., Spang, A., Könneke, M., Schintlmeister, A., Urich, T., Engel, M., Schloter, M., Wagner, M., Richter, A., and Schleper, C. (2011). Nitrososphaera viennensis, an ammonia oxidizing archaeon from soil. Proc. Natl. Acad. Sci. U.S.A. 20, 8420-8425.

Treusch, A. H., Leininger, S., Kletzin, A., Schuster, S. C., Klenk, H. P., and Schleper, C. (2005). Novel genes for nitrite reductase and Amo-related proteins indicate a role of uncultivated mesophilic crenarchaeota in nitrogen cycling. Environ. Microbiol. 7, 1985-1995.

van Groenigen, K. J., Osenberg, C. W., and Hungate, B. A. (2011). Increased soil emissions of potent greenhouse gases under increased atmospheric $\mathrm{CO}_{2}$. Nature 475, 214-216.

Verhamme, D. T., Prosser, J. I., and Nicol, G. W. (2011). Ammonia concentration determines differential growth of ammonia-oxidizing archaea and bacteria in soil microcosms. ISME J. 5, 1067-1071.

Venter, C. J., Remington, K., Heidelberg, K. J., Halpern, A. L., Rusch, D., Eisen, J. A., Wu, D., Paulsen, I., Nelson, K. E., Nelson, W., Fouts, D. E., Levy, S., Knap, A. H., Lomas, M. W., Nealson, K., White, O., Peterson, J., Hoffman, J., Parsons, R., BadenTillson, H., Pfannkoch, C., Rogers, Y. H., and Smith, H. O. (2004). Environmental genome shotgun sequencing of the Sargasso Sea. Science 304, 66-74.

Walker, C. B., de la Torre, J. R., Klotz, M. G., Urakawa, H., Pinela,
N., Arp, D. J., Brochier-Armanet, C., Chain, P. S., Chan, P. P., Gollabgir, A., Hemp, J., Hügler, M. Karr, E. A., Könneke, M., Shin, M., Lawton, T. J., Lowe, T., MartensHabbena, W., Sayavedra-Soto, L. A., Lang, D., Sievert, S. M., Rosenzweig, A. C., Manning, G., and Stahl, D. A. (2010). Nitrosopumilus maritimus genome reveals unique mechanisms for nitrification and autotrophy in globally distributed marine crenarchaea. Proc. Natl. Acad. Sci. U.S.A 107, 8818-8823.

Wang, S., Xiao, X., Jiang, L., Peng, X., Zhou, H., Meng, J., and Wang, F. (2009). Diversity and abundance of ammonia-oxidizing archaea in hydrothermal vent chimneys of the Juan de Fuca Ridge. Appl. Environ. Microbiol. 75, 4216-4220.

Wessén, E., Nyberg, K., Jansson, J. K., and Hallin, S. (2010). Responses of bacterial and archaeal ammonia oxidizers to soil organic and fertilizer amendments under long-term management. Appl. Soil Ecol. 45, 193-200.

Wuchter, C., Abbas, B., Coolen, M., Herfort, L., Bleijswijk, J., Timmers, P., Strous, M., Teira, E., Herndl, G. J., Middelburg, J. J., Schouten, S., and Sinninghe Damsté, J. S. (2006). Archaeal nitrification in the ocean. Proc. Natl. Acad. Sci. U.S.A. 103, 12317-12322.

Yao, H., Gao, Y., Nicol, G. W., Campbell, C. D., Prosser, J. I., Zhang, L., Han, W., and Singh, B. K. (2011). Links between ammonia oxidizer community structure, abundance, and nitrification potential in acidic soils. Appl. Environ. Microbiol. 77, 4618-4625.

Xu, M., Schnorr, J., Brandon Keibler, B., and Simon, H. M. (2012). Comparative analysis of $16 \mathrm{~S}$ rRNA and amoA genes from archaea selected with organic and inorganic amendments in enrichment culture. Appl. Environ. Microbiol. 78, 2137-2146.

Zhang, C. L., Ye, Q., Huang, Z., Li, W., Chen, J., Song, Z., Zhao, W., Bagwell, C., Inskeep, W. P., Ross, C., Gao, L., Wiegel, J., Romanek, C. S., Shock, E. L., and Hedlund, B. P. (2008). Global occurrence of archaeal amoA genes in terrestrial hot springs. Appl. Environ. Microbiol. 74, 6417-6426.

Zhang, L., Hu, H., Shen, J., and He, J. (2011). Ammonia-oxidizing archaea have more important role than ammonia-oxidizing bacteria in ammonia oxidation of strongly acidic soils. ISME J. 6, 1032-1045.

Zhang, L., Offre, P. R., He, J. Z., Verhamme, D. T., Nicol, G. W., and 
Prosser, J. I. (2010). Autotrophic ammonia oxidation by soil thaumarchaea. Proc. Natl. Acad. Sci. U.S.A. 107, 17240-17245.

Zhang, L. M., Wang, M., Prosser, J. I., Zheng, Y. M., and He, J. Z. (2009). Altitude ammonia-oxidizing bacteria and archaea in soils of Mount Everest. FEMS Microbiol. Ecol. 70, 208-217.

Zheng, X., Wang, M., Wang, Y., Shen, R., Ji Gou, J., Li, J., Jin, J., and Li,
L. (2000). Impacts of soil moisture on nitrous oxide emission from croplands: a case study on the rice-based agro-ecosystem in Southeast China. Chemosphere Global Change Sci. 2, 207-224.

Conflict of Interest Statement: The authors declare that the research was conducted in the absence of any commercial or financial relationships that could be construed as a potential conflict of interest.

Received: 15 March 2012; paper pending published: 05 May 2012; accepted: 22 May 2012; published online: 15 June 2012.

Citation: Zhalnina K, Dörr de Quadro P, Camargo FAO and Triplett EW (2012) Drivers of archaeal ammonia-oxidizing communities in soil. Front. Microbio. 3:210. doi: 10.3389/fmicb.2012.00210
This article was submitted to Frontier in Terrestrial Microbiology, a specialty of Frontiers in Microbiology.

Copyright (c) 2012 Zhalnina, Dörr de Quadros, Camargo and Triplett. This is an open-access article distributed under the terms of the Creative Common Attribution Non Commercial License, which permits non-commercial use, distribution, and reproduction in other forums, provided the original authors and source are credited. 